Osmaniye Korkut Ata University
Journal of Natural and Applied Sciences
Volume 3, Issue 2, 83-89, 2020

\title{
Hatay İlinde Üretilen Bazı Kuru Kaba Yemlerin Besin Madde İçeriklerinin Belirlenmesi
}

\author{
Süleyman ZAHAL ${ }^{1}$, Şerafettin KAYA ${ }^{2 *}$ \\ ${ }^{1}$ Hatay Mustafa Kemal Üniversitesi, Fen Bilimleri Enstitüsü, Zootekni Anabilim Dalı,31100, Antakya/HATAY \\ ${ }^{2}$ Hatay Mustafa Kemal Üniversitesi, Ziraat Fakültesi, Zootekni Bölümü,31100, Antakya/HATAY \\ ${ }^{1}$ https://orcid.org/0000-0002-5594-8849 \\ ${ }^{2}$ https://orcid.org/0000-0001-9744-8714 \\ *Sorumlu yazar: serafettinkaya@gmail.com
}

\section{Araştırma Makalesi}

\section{Makale Tarihçesi:}

Geliș tarihi: 8 Haziran 2020

Kabul tarihi:28 Temmuz 2020

Online Yayınlanma:15 Aralık 2020

\section{Anahtar Kelimeler:}

Ruminant

Kuru kaba yem

Besin madde içeriği

ME düzeyi

\begin{abstract}
ÖZET
Bu çalışmada, Hatay'da üretilen ve ruminantların beslenmesinde yaygın olarak kullanılan bazı kuru kaba yemlerin besin madde içeriklerinin belirlenmesi amaçlanmıştır. Bu amaca yönelik olarak Hatay ili genelinde 19 adet buğday samanı, 18 adet yonca kuru otu (YKO), 2 adet fiğ kuru otu, 2 adet mercimek samanı, 1 adet yer fistığı kuru otu, 4 adet karışık çayır kuru otu (ÇKO) olmak üzere 46 adet kuru kaba yem örneklenmiştir. Örneklenen kaba yemlerde KM, HK, $\mathrm{HP}, \mathrm{HY}, \mathrm{OM}, \mathrm{HS}, \mathrm{ADF}, \mathrm{NDF}$ ve ADL düzeyleri belirlenmiş ve kaba yemlerin ME düzeyleri hesaplama yoluyla tespit edilmiştir. Besin madde içerikleri YKO için HP $\% 15,58$, HS \%32,84, ADF \%37,52, NDF \%44,38 ve ME düzeyi $1727 \mathrm{kcal} / \mathrm{kg}$ olarak, Fiğ kuru otu için aynı sırayla \%13,96, \%31,26, \%32,68, \%43,31 ve 1766 $\mathrm{kcal} / \mathrm{kg}$ ME, buğday samanı için de $\% 3,22, \% 41,04, \% 48,40, \% 68,60$ ve 864 $\mathrm{kcal} / \mathrm{kg}$ ME olarak tespit edilmiştir. Çalışmada elde edilen değerlerin söz konusu kuru kaba yemler için gerek yapılan önceki çalışmalarda gerekse yemlerin besin madde içeriklerini açıklayan ve genel kabul gören tablo değerlerine uyumlu olduğu, arada ortaya çıkan farklılıkların yem bitkisinin çeşidine, yetiştiricilik yapılan bölgenin iklim ve toprak özelliklerine bağlı olduğu söylenebilir.
\end{abstract}

\section{Determination of Nutrient Contents of Some Roughages Produced in Hatay}

\section{Research Article}

\section{Article History:}

Received: 8 June 2020

Accepted: 28 July 2020

Published online: 15 December 2020

\section{Keywords:}

Ruminant

Roughages

Nutrient content

ME level

\begin{abstract}
This resarch was conducted to determine of nutrient contents of some roughages produced in Hatay province. For this purpose, 46 dry coarse samples including 19 wheat straw, 18 alfalfa hay, 2 vetch hay, 2 lentil straw, 1 peanut hay, 4 mixed meadow hay were sampled in Hatay province. DM, Ash, CP, EE, OM, CF, ADF, NDF, ADL and ME levels of roughages were determined. The nutrient contents of alfalfa hay were determined for $\mathrm{CP} 15,58 \%$, CF 32,84\%, ADF 37,52\%, NDF $44.38 \%$ and $\mathrm{ME}$ level was $1727 \mathrm{kcal} / \mathrm{kg} \mathrm{ME}$ and for vetch hay, 13,96\%, 31,26\%, $32,68 \%, 43,31 \%$ and $1766 \mathrm{kcal} / \mathrm{kg} \mathrm{ME}$ and for wheat straw, 3,22\%, 41,04\%, $48,40 \%, 68,60 \%$ and $864 \mathrm{kcal} / \mathrm{kg} \mathrm{ME}$, respectively. It can be said that the values obtained in the study were consistent with the both of reference values and the previous studies, occurred some differences can be explained differences of plants, climatic conditions and soil characteristics of the breeding area.
\end{abstract}

To Cite: Zahal S., Kaya Ş. Hatay İlinde Üretilen Bazı Kuru Kaba Yemlerin Besin Madde İçeriklerinin Belirlenmesi. Osmaniye Korkut Ata Üniversitesi Fen Bilimleri Enstitüsü Dergisi 2020; 3(2): 83-89. 


\section{Giriş}

İşletmenin karlılığını, verim ve kalite gibi hususları etkilediği düşünüldüğünde, hayvanların kaliteli kaba yemler ile beslenmesi büyük bir zorunluluktur. Yem bitkileri ve hayvancilığı gelişmiş olan ülkelerde kaliteli kaba yem üretimi konusunda bir problem görülmez iken, ülkemizde kaliteli kaba yem üretim potansiyeli yeterli olmamakla birlikte, yıldan yıla artı̣ göstermeye başlamışıır [1].

Kaba yemlerin ucuz olmasinın yanı sira ruminantlarda rumen mikroflorasında gerekli enzimlerin salgılanmasına yardımcı oluşu ve hayvan gelişimi için gerekli protein, yağ ve selülozu içermesi, mineral ve vitaminlerce zengin olması, hayvanların performansını iyileştirmesi, beslenmeye bağlı birçok metabolik hastalığın önlenmesi ve yüksek kalitede verimliliğin sağlanması bakımından da önemlidir [2].

Hayvanların kaba yem ihtiyaçları, doğal çayır ve meralar, yem bitkileri (yonca, korunga, fiğ, bakla, bezelye, sorgum ve hasil misır), harman kalıntıları (buğdaygil ve baklagil samanları, kavuzlar) ile yeşil ve su bakımından zengin (posa ve cibre) yemlerden karşılanmaktadır [3].

Hatay ili 275,578 ha tarım alanına sahiptir. Bu alanın 160,842 ha'1 tarla alanı olarak kullanılırken, 5061 da fĭg (yeşil ot), 3636 da yonca, 10 da hasıl mısır, 19.709 da I. ve II. ürün silajlık misır ekimi yapılarak; bu alanlardan 6115 ton fiğ , 12,438 ton yonca, 35 ton hasil misir ve 87,735 ton mısır silajı üretimi gerçekleştirilmiștir [4].

Yaklaşık 747,651 da alanda dane olarak buğday, yulaf, arpa ve misir üretimi yapilarak, toplam $1,250.079$ ton ürün elde edilmiştir. Bu miktar dane üretiminde ortalama $1 / 4$ oranında saman ve hasat artıkları üretimi hesabıyla yaklaşık 312,500 ton civarında da saman vb. kaba yem üretimi söz konusudur [4].

Çalışmanın yürütüldüğü Hatay ilinin hayvan varlığı, 149,734 büyükbaş $(95,304$ saf kültür $1 r k 1$, 45,498 baş kültür melezi ve 8932 baş yerli sı̆̆ır ve manda) ve 391,359 baş küçükbaş $(233,089$ baş koyun ve 158,270 baş keçi) olarak bildirilmektedir [4].

$\mathrm{Bu}$ verilere göre ilin Büyükbaş Hayvan Birimi (BBHB), (500 kg canlı ağırlık = 1 BBHB) cinsinden hayvan varlığ 188,870 baş olarak bulunmuştur. $500 \mathrm{~kg}$ canlı ağırlığındaki bir kültür 1rk1 sığır (1 BBHB)'ın yaşam payı besin madde ihtiyacını karşılamak için yaklaşı $10 \mathrm{~kg} / \mathrm{gün}$ kaliteli kuru ot gerekmektedir [5]. Buna göre Hatay'da bulunan 188,870 BBHB için yılda $(188,870 \times 10 \mathrm{~kg} /$ gün $\times 365$, gün) 689,375 ton civarında kaliteli kaba yem gereksinimi vardır.

Önceki paragrafta belirtildiği üzere ilin toplam hayvan varlığı üzerinden kaliteli kaba yem gereksinimi 689,375 ton iken, üretilen kaba yem toplam 100,208 ton $(12,438$ ton kuru ot $+87,770$ ton silaj-hasıl olarak kaliteli kaba yem) ve 312,500 ton tahil sap ve samanı ile ancak 412,708 ton olarak gerçekleşmektedir. Üretilen kaynağın hepsi kaliteli olmamakla birlikte 276,667 ton kaba yem açığı gerçekleşmektedir.

Ruminant hayvanların beslenmesinde kullanılan kuru kaba yemler yetersiz kalmakla birlikte ürünlerin kaliteleri bilinmemekte ve farklı sebeplerle değişiklik göstermektedir. Hayvanların rasyonel ve dengeli beslenmesini sağlamak ve birim yemden elde edilen verimi arttırabilmek adına kaba yemlerin besin madde içeriklerinin bilinmesi ayrıca önemlidir.

Türkiye'de üretilen kaba yemlerin bölgelere göre besin madde içeriklerini gösteren standart tabloların olmaması, farklı bölgelerden sağlanan kaba yemlerin besin madde içerikleri hakkında sağlıklı bilgi edinilmesini engellemektedir [3].

$\mathrm{Bu}$ çalışmada Hatay ilinde üretilen ve ruminantların beslenmesinde yaygın olarak kullanılan bazı kaba yemlerin besin madde içeriklerinin belirlenmesi amaçlanmıştır.

\section{Materyal ve Metod}

Çalışmanın materyalini Hatay ili ve ilçelerindeki hayvancılık işletmelerinden örneklenen kuru kaba yemler oluşturmuş̧tur.

Elde edilen ve çeşitli yem bitkilerine ait 46 adet kuru kaba yem numunesi içerik olarak analiz edilerek veriler elde edilmiştir. Araştırmada örneklenen kuru kaba yemler 1 mm'lik elekten geçecek ş̧ekilde ögütülmüştür. Yem bitkisi örnekleri alındıkları bölgelere, işletme tipine, üretim tarihine, depolama şekline göre etiketlenmiş ve +4 derecede kağıt torbalar içerisinde muhafaza edilmiştir.

Çalışmada kullanılan toplam 46 yem bitkisi örneğinin; 19 adedi buğday samanı, 18'i yonca kuru otu, 2'si fiğ kuru otu, 2'si mercimek saman1, 
1'i yer fistığı kuru otu ve 4 adedi ise karışık çayır kuru otundan oluşmuştur.

Örneklenen kaba yemlerde; kuru madde (KM), ham kül (HK), ham protein (HP) ve ham yağ $(\mathrm{HY})$, organik madde (OM) içerikleri (AOAC, 1984) [4]'e göre; ham selüloz (HS), asit deterjan lif (ADF), nötr deterjan lif (NDF) ve asit deterjan lignin (ADL) miktarları ise ANKOM teknolojisi ile (Ankom 200 Fiber Analyzer Tech) yapılmıştır [6].

Kaba yemlerin ME düzeyleri;

MEHS, $\mathrm{kcal} / \mathrm{kg} \mathrm{KM}=3309,5-35,64 \times \mathrm{HS}$

formülü kullanılarak hesaplanmıştır [7].
Verilerin istatistiki olarak ortalama, min-max değerleri ile standart dağılımları SPSS paket programı (SPSS 22nd Ed.) kullanilarak hesaplanmıştır.

\section{Bulgular ve Tartışma}

Çalışmada örneklenen kuru kaba yemlerin besin madde analiz sonuçları Çizelge 1'de verilmiştir.

Türkiye genelinde olduğu gibi Hatay ili örneğinde de hayvanc1lık işletmelerinin kaba yem kaynağ 1 olarak kullandığı ana materyal çeşitli tahıl üretimi artığ1 olan samanlar $(\mathrm{n}=19)$ olarak karşımıza çıkmıştır. Bununla birlikte yonca $(\mathrm{n}=18)$, fĭg $(\mathrm{n}=2)$ ve karışık çayır otu $(n=4)$ gibi kaliteli kuru kaba yemler de işletmeler tarafindan hayvan beslemede kullanılmaktadır.

Çizelge 1. Hatay ilinin farklı yerlerinden örneklenen kuru kaba yemlerin besin madde içerikleri

\begin{tabular}{|c|c|c|c|c|c|c|c|c|c|c|}
\hline $\begin{array}{l}\text { Yem } \\
\text { Hammaddeleri }\end{array}$ & $\begin{array}{c}\text { KM, \% } \\
\text { X } \\
\text { Min-Maks } \\
\text { SD }\end{array}$ & $\begin{array}{c}\text { HK, \% } \\
\text { X } \\
\text { Min- } \\
\text { Maks } \\
\text { SD } \\
\end{array}$ & $\begin{array}{c}\text { OM, } \% \\
\text { X } \\
\text { Min-Maks } \\
\text { SD }\end{array}$ & $\begin{array}{c}\text { HP, } \% \\
\text { X } \\
\text { Min-Maks } \\
\text { SD }\end{array}$ & $\begin{array}{c}\text { HS, } \% \\
\text { X } \\
\text { Min-Maks } \\
\text { SD }\end{array}$ & $\begin{array}{c}\text { HY, \% } \\
\text { X } \\
\text { Min-Maks } \\
\text { SD }\end{array}$ & $\begin{array}{c}\text { ADF, } \% \\
x \\
\text { Min-Maks } \\
\text { SD }\end{array}$ & $\begin{array}{c}\text { NDF, \% } \\
\text { X } \\
\text { Min-Maks } \\
\text { SD }\end{array}$ & $\begin{array}{c}\text { ADL, } \% \\
\text { X } \\
\text { Min-Maks } \\
\text { SD }\end{array}$ & $\begin{array}{c}\text { ME,kcal/kg } \\
\text { x } \\
\text { Min-Maks } \\
\text { SD }\end{array}$ \\
\hline $\begin{array}{l}\text { YKO } \\
(\mathrm{n}=18)\end{array}$ & $\begin{array}{c}89,24 \\
87,47-90,90 \\
0,83\end{array}$ & $\begin{array}{c}9,88 \\
6,92-12,92 \\
1,90\end{array}$ & $\begin{array}{c}79,35 \\
76,89-82,26 \\
1,81\end{array}$ & $\begin{array}{c}15,58 \\
11,96-20,94 \\
2,27\end{array}$ & $\begin{array}{c}32,84 \\
24,37-38,58 \\
3,90\end{array}$ & $\begin{array}{c}1,05 \\
0,60-1,95 \\
0,32\end{array}$ & $\begin{array}{c}37,52 \\
29,19-50,03 \\
5,39\end{array}$ & $\begin{array}{c}44,38 \\
36,81-49,70 \\
4,26\end{array}$ & $\begin{array}{c}12,02 \\
8,22-20,96 \\
3,25\end{array}$ & $\begin{array}{c}1727 \\
1538-1997 \\
151\end{array}$ \\
\hline $\begin{array}{l}\text { Buğday Samanı } \\
(n=19)\end{array}$ & $\begin{array}{c}90,85 \\
87,92-91,81 \\
0,81\end{array}$ & $\begin{array}{c}10,28 \\
7,63-13,28 \\
1,93\end{array}$ & $\begin{array}{c}80,57 \\
77,50-83,23 \\
1,75\end{array}$ & $\begin{array}{c}3,22 \\
2,40-4,47 \\
0,58\end{array}$ & $\begin{array}{c}41,04 \\
36,05-61,40 \\
5,48\end{array}$ & $\begin{array}{c}0,99 \\
0,46-1,59 \\
0,32\end{array}$ & $\begin{array}{c}48,40 \\
43,21-52,58 \\
2,66\end{array}$ & $\begin{array}{c}68,60 \\
65,04-72,73 \\
1,92\end{array}$ & $\begin{array}{c}12,11 \\
9,79-15,90 \\
1,63\end{array}$ & $\begin{array}{c}864 \\
717-991 \\
68\end{array}$ \\
\hline $\begin{array}{l}\text { Mercimek Samanı } \\
(\mathrm{n}=2)\end{array}$ & $\begin{array}{c}90,42 \\
89,81-91,04 \\
0,86\end{array}$ & $\begin{array}{c}12,06 \\
9,53-14,60 \\
3,58\end{array}$ & $\begin{array}{c}78,36 \\
75,21-81,51 \\
4,54\end{array}$ & $\begin{array}{c}6,23 \\
5,93-6,53 \\
0,42\end{array}$ & $\begin{array}{c}37,32 \\
36,49-38,16 \\
1,18\end{array}$ & $\begin{array}{c}1,47 \\
1,20-1,75 \\
0,38\end{array}$ & $\begin{array}{c}38,20 \\
37,14-39,26 \\
1,49\end{array}$ & $\begin{array}{c}49,84 \\
49,44-50,26 \\
0,57\end{array}$ & $\begin{array}{c}13,38 \\
11,72-15,05 \\
2,35\end{array}$ & $\begin{array}{c}1533 \\
1518-1547 \\
20\end{array}$ \\
\hline Yer Fis KO $(n=1)$ & 90,21 & 9,72 & 80,49 & 5,66 & 37,59 & 1,14 & 35,68 & 46,02 & 10,28 & 1669 \\
\hline $\begin{array}{l}\text { Karışık } \\
(\mathrm{n}=4)\end{array}$ & $\begin{array}{c}89,64 \\
88,32-90,73 \\
1,08\end{array}$ & $\begin{array}{c}10,07 \\
8,35-12,03 \\
1,62\end{array}$ & $\begin{array}{c}79,57 \\
77,63-81,52 \\
1,92\end{array}$ & $\begin{array}{c}9,27 \\
4,51-13,78 \\
4,53\end{array}$ & $\begin{array}{c}35,25 \\
30,75-39,65 \\
3,86\end{array}$ & $\begin{array}{c}1,05 \\
0,72-1,55 \\
0,35\end{array}$ & $\begin{array}{c}39,47 \\
33,06-46,97 \\
5,93\end{array}$ & $\begin{array}{c}57,16 \\
45,43-68,35 \\
10,39\end{array}$ & $\begin{array}{c}7,03 \\
4,63-10,03 \\
2,38\end{array}$ & $\begin{array}{c}1272 \\
874-1690 \\
370\end{array}$ \\
\hline $\begin{array}{l}\text { Fiğ KO } \\
(n=2)\end{array}$ & $\begin{array}{c}88,39 \\
88,31-88,47 \\
0,11 \\
\end{array}$ & $\begin{array}{c}7,61 \\
7,51-7,72 \\
0,15 \\
\end{array}$ & $\begin{array}{c}80,77 \\
80,75-80,80 \\
0,04 \\
\end{array}$ & $\begin{array}{c}13,96 \\
11,92-16,00 \\
2,88 \\
\end{array}$ & $\begin{array}{c}31,26 \\
29,03-33,50 \\
3,16 \\
\end{array}$ & $\begin{array}{c}1,0 \\
0,70-1,31 \\
0,43\end{array}$ & $\begin{array}{c}32,68 \\
29,81-35,57 \\
4,07 \\
\end{array}$ & $\begin{array}{c}43,31 \\
41,54-45,10 \\
2,52 \\
\end{array}$ & $\begin{array}{c}7,33 \\
6,70-7,97 \\
0,89 \\
\end{array}$ & $\begin{array}{c}1766 \\
1702-1829 \\
90 \\
\end{array}$ \\
\hline
\end{tabular}

Çalı̧̧mada örneklenen 18 adet YKO'nun \%KM değeri 87,47-90,90 arasında değişim göstermiş ve ortalama \%89,24 olarak belirlenmiştir.

Örneklerin \%66,67'sinin $(n=12) \% \mathrm{KM}$ değeri 89,01-90,00 aralığında tespit edilmiştir. Elde edilen değerler bazı çalışmalarda YKO için bildirilen değerlere eş [8], bazı bildirişlerden yüksek [9, 10], diğer bazı araştırıcıların bulgularından düşük olarak tespit edilmiştir [11, $12,13,14,15]$.

Örneklenen YKO'nun \%HP değerleri \%11,96 ile $\% 20,94$ arasında dağılım göstermiş ve ortalama $\% 15,58$ olmuştur. $\mathrm{Bu}$ değerler örneklenen YKO'larının istenilen oranda HP içerdiğinin göstergesi olarak kabul edilmiştir. Tespit edilen ortalama \%15,58 HP değeri bazı bildirişlerden yüksek [10, 11, 13, 14], diğer bazı çalışmalarda elde edilen değerlerden ise düşük olmuştur [16, $17,18,19]$.

On sekiz YKO örneğinin 7 adedi $(\% 38,89)$ $\% 32,01-36,00$ HS içerirken, 5 adedi $(\% 27,77)$ ise \%34,01-39,00 aralığında HS içermiștir. YKO'nu vejetasyon dönemine göre (çiçeklenme başı, 1/10 çiçeklenme, tam çiçek ve tohum) analiz eden araştırıcıların bulgularına göre elde edilen HS düzeyleri tam çiçek dönemine uymaktadır [14, 20].

Kaba yemlerdeki sindirilebilirlik; otlardaki selüloz, hemiselüloz ve lignin gibi hücre duvarını oluşturan madde miktarlarıyla ilişkilidir. Son 
y1llarda otlardaki sindirilebilirlik oranları ADF ve NDF üzerinden hesaplanmaktadır. ADF, daha çok bir kaba yemin hayvan tarafindan sindirilebilirlik durumunun belirlemesinde kullanılan bir yem değeri iken, NDF ise kaba yemlerin hayvanlar tarafindan alınabilirlik durumlarının saptanmasında kullanılan bir yem değeridir [21]. İyi bir ot kalitesi için ADF ve NDF değerlerinin mümkün olduğu kadar düşük olmas1 istenilmektedir [22, 23, 24, 25, 26, 27].

YKO'unda \%ADF ortalama 37,52, \%NDF ise ortalama 44,38 olarak tespit edilmiş, ME değerleri $1538-1997 \mathrm{kcal} / \mathrm{kg}$ arasında değişmiş ve ortalama $1727 \mathrm{kcal} / \mathrm{kg}$ olarak hesaplanmıştır.

Tahılların tane üretimi amaçlı hasat artığı olan samanlardan buğday samanının KM değerleri \%87,92-91,81 aralı̆̆ında dağılım göstererek ortalama \%90,85 olduğu tespit edilmiştir.

Samanlar düşük besin madde ve yüksek selüloz içerikli kaba yem olarak tanımlandıklarından dolayı bu özelliklerine bağlı olarak buğday samanının HP değerleri de düşük olmuştur. Buğday samanının HP değerleri \%2,40-4,47 aralığında değişmiş ve ortalama $\% 3,22$ olarak tespit edilmiştir.

Buğdaygil kuru otları baklagil kuru otlarına göre daha yüksek oranda ADF ve NDF içermektedirler [25]. Bu gerçek, yapılan analizlerde elde edilen değerlerle buğday samanının ADF ve NDF içeriklerinde de ortaya konmuş olmaktadır. Buğday samanı ortalama \%48,40 (\%43,51-52,58) ADF, \%68,60 (65,04-72,73) NDF içeriği ile YKO'ndan daha yüksek değerlere sahip olmuştur.

Yürütülen araştırmada buğday samanı için tespit edilen ADF ve NDF değerleri bazı çalışmalarda elde edilen bulgulardan yüksek olurken [9], diğer bazı çalışmalarda elde edilen bulgulardan daha düşük olarak tespit edilmiştir $[8,10,11,28]$.

Samanların besin madde içeriği bakımından bir diğer özelliği de yüksek oranda selüloz içermeleridir. Bitkilerin hayat devrelerini tamamlamalarından sonra elde edildiklerinden selüloz içerikleri yüksek olmakta ve bu nedenle de sindirilme dereceleri ve besleme değerleri oldukça düşük olmaktadır. Örneklenen buğday samanlarının HS düzeyleri \%36,05-61,40 aralığında ortalama \%41,04 olarak belirlenmiştir. Buğday samanlarında HS bulguları benzer konuda yapılan araştırmalarda elde edilen değerlerden daha yüksek iken $[9,11,13,29]$, diğer araştırıcıların bulgularından daha düşük olarak tespit edilmiştir [8, 10, 17, 28].

Çalışmada örneklenen buğday samanının ME değerleri $717-991 \mathrm{kcal} / \mathrm{kg}$ aralığında ve ortalama $864 \mathrm{kcal} / \mathrm{kg}$ olarak hesaplanırken, buğday samanlarının \%63,16'sının (n=ME değeri 800-900 $\mathrm{kcal} / \mathrm{kg}$ aralığında yer almıştır.

Çalışmada örneklenen 4 adet karışık çayır otunun \%HP değeri 4,51-13,78 aralığında değişmiş, bu durum çayır kuru otunun elde edildiği alanlardaki bitki kompozisyonunun çok farklı olduğunun bir göstergesi olarak değerlendirilmiştir. Çayır kuru otu örneklerinin HS düzeyi \%30,75-39,65 aralığında tespit edilmiştir. HS içeriği bakımından çalışmada örneklenmiş çayır kuru otunun analizi ile elde edilen sonuçlar önceki dönemde yapılan benzer çalışmalarda elde edilen değerlerden daha yüksek olmuştur $[12,13,17,30]$.

Sahadan tek örnek olarak analiz edilen yerfistığ kuru üst aksamı KM, HP, HS, HY, ADF, NDF ve ME değerleri \% olarak sirasıyla 90,21, 5,66, $37,59,1,14,35,68,46,02$ ve $1669 \mathrm{kcal} / \mathrm{kg}$ olarak tespit edilmiştir. Yer fistığı üst aksamının HP içeriği $[31,32,33,34]$ ve ADF değeri [30 ve 33] önceki bildirişlerden daha düşük olmuştur. Analizi yapılan örnekte NDF değeri bakımından ise elde edilen değer kimi araştırıcıların elde ettiği değerden yüksek [31, 32], bazı araştırıcıların bildirişinden daha düşük [34] olarak tespit edilmiştir.

Çalı̧̧mada iki adet örneklenen mercimek samanı baklagil samanı olmas1 dolayıs1 ile örneklenen buğday samanlarından daha kaliteli bir görüntü vermiştir. Bu bağlamda mercimek samanının KM, HK, HP, HS, ADF, NDF ve ME değerleri sirasiyla \%90,42, \%12,06, \%6,23, \%37,32, $\% 38,20, \% 49,84$ ve $1533 \quad \mathrm{kcal} / \mathrm{kg}$ olarak bulunmuştur. Mercimek samanı örnekleri, KM, HP, ADF ve NDF bakımından önceki bildirilen değerlerden düşükken, HK ve HS içeriği bakımından ise daha yüksek değere sahip olmuştur [11].

Çalışmada ayrıca, fïğ bitkisine ait KM, HK, OM, HP, HS, HY, ADF, NDF ve ME değerleri sirasiyla \%88,39, \%7,61, \%80,77, \%13,96, $\% 31,26, \% 1,0, \% 32,68, \% 43,31$ ve $1766 \mathrm{kcal} / \mathrm{kg}$ olarak tespit edilmiştir. 


\section{Sonuç ve Öneriler}

Hatay'da üretilen ve ruminantların beslenmesinde yaygin olarak kullanılan kaba yemlerin besin madde içeriklerinin belirlenmesi amacıyla yürütülen bu çalışmada;

Örneklerin besin madde analiz sonuçlarının daha önce yapılan çalışmalarda elde edilen ve hayvan beslemede genel kabul görerek kullanılan yem değerleri tablosundaki değerlerle uyumlu olduğu,

Örneklerde arasındaki besin madde içeriği farklılıklarının önceki çalışmalarda da belirtildiği gibi yem bitkisinin çeşidi, yetiştiriciliği yapılan bölgenin toprak ve iklim özelliklerine bağlı olarak ortaya çıkabileceği,

Baklagil ve buğdaygil kaba yemlerin HP, HS, $\mathrm{ADF}$ ve NDF içerikleri yönünden bilinen farklılıklarının bu çalışmada da belirlendiği,

Ülkemiz hayvancılığında olduğu gibi ruminant hayvanların beslenmesinde en fazla kullanilan kuru kaba yemin, besin değeri düşük tahıl samanları (çalışmamızda buğday samanı) olduğu,

Ülkemizde mevcut hayvanların yeterli beslenmesi için hali hazırda kaba yem olarak en fazla kullanılan tahıl samanı yerine kaliteli kaba yem üretimi için yem bitkileri ekiminin artırılması ve üretilen bu kaba yemlerin de besin madde içeriklerinin bilinmesi ve tablolar halinde yayınlanması gerektiği,

Besin madde içeriğgi bilinen kuru kaba yemlerin hayvan beslemede kullanılırken, hedef hayvanın gereksinimini karşılayacak şekilde rasyona katkısının bilinmesi ile hayvansal üretimde ekonomiklik sağlanacağı söylenebilir.

\section{Teşekkür}

Bu makale "Hatay İlinde Üretilen Bazı Kuru Kaba Yemlerin Besin Madde İçeriklerinin Belirlenmesi" başlıklı Yüksek Lisans tezinin bir parçası olarak hazırlanmıştır. Yazarlar, çalışmaya finansal destek sağlayan HMKU Bilimsel Araştırma Projeleri Koordinatörlüğü'ne (Proje No: 17 YL 015) teşekkür eder.

\section{Kaynakça}

[1] Özkan U., Demirbağ NŞ. Türkiye'de kaliteli kaba yem kaynaklarının mevcut durumu, Türk Bilimsel Derlemeler Dergisi 2016; 9 (1): 23-27.

[2] Karaköy T., Saraç H. Sivas ekolojik koşullarında yetiştirilen yonca çeşitlerinin bazı agronomik ve kalite özelliklerinin incelenmesi, Türk Tarım ve Doğa Bilimleri Dergisi 2018; 5(4): 620-627.

[3] Güngör T., Başalan M., Aydoğan İ. Kırıkkale yöresinde üretilen bazı kaba yemlerde besin madde miktarları ve metabolize olabilir enerji düzeylerinin belirlenmesi. Ankara Üniv Vet Fak Derg 2008; 55, 111-115.

[4] Anonim, 2017. 2017 y1l faaliyet raporu. Hatay Valiliği İl Gıda, Tarım ve Hayvancılık Müdürlüğü.

(Erișim: https://hatay.tarimorman.gov.tr/Menu/55/Tari msal-Veriler, Erişim Tarihi: 16.05.2019)

[5] Gökkuş A., Kantar F., Karadoğan T., Koç A. Tarla Bitkileri (2. Bask1). Atatürk Üni., Ziraat Fak. Ders Yay. No: 188, Erzurum, 1998.

[6] AOAC. Official Methods of Analysis, 15th edition. Assoc. Off. Anal. Chem., Arlington, VA, 1990.

[7] Van Soest PJ., Robertson JB., Lewis BA. Methods for fiber, neutral detergent fiber and nonstarch polysaccharides in relation to animal nutrition. J. Dairy Sci 1991; 74, 35833597.

[8] Kirchgessner M., Kellner RJ. Estimation of metabolizable energy from forage by means of simple criteria, Z Tierphysiol Tierernahr Futtermittelkd 1977; 38(6): 297-301.

[9] Gündüz Y. İşletme Koşullarında Kullanılan Bazı Yemlerin Besin Madde Kompozisyonu ve Mikrobiyolojik Özellikleri. Yüksek Lisans Tezi, NKÜ FBE Zootekni Anabilim Dalı, 63 syf, Tekirdağ, Türkiye, 2013.

[10] Değirmencioğlu T. Kimi kaba yemlerin koyun ve keçilerde in-vitro sindirilebilirliklerinin mukayesesi üzerine bir araştırma, UÜ Ziraat Fakültesi Dergisi 2004; 18(1): 157-165.

[11] Preston RL. 2016 Feed Composition Table. beefmagazine.com. March 2016, pp. 16-34. 
(https://www.beefmagazine.com/sites/beefma gazine.com/files/2016-feed-compositiontables-beef-magazine.pdf)

[12] Şehu A., Yalçın S., Önol AG., Koçak D. Kaba yemlerin bazı özelliklerinden yararlanarak kuzularda kuru madde tüketimi ve canlı ağırlık artışının belirlenmesi, Tr. J. of Veterinary and Animal Sicences 1998; 22, 475-483.

[13] Çerçi İH., Tatlı Seven P., Azman MA., Birben N. Koyunlarda bazı kaba ve yoğun yemlerin naylon kese yöntemiyle kuru ve organik madde yıkımlanabilirliklerinin ve enzim tekniği ile kuru ve organik madde sindirilebilirliklerinin saptanması, FÜ Sağlık Bil. Dergisi 2004; 18(2): 111-116.

[14] Denek N., Deniz S. Ruminant beslemede yaygın olarak kullanılan kimi kaba yemlerin sindirilebilirlik ve metabolik enerji düzeylerinin in vitro metotlarla belirlenmesi, Türk J Vet Anim Sci. 2004; 28, 115-122.

[15] Ünalp E. Farklı Gelişme Dönemleri ve Biçim Siralarında Yonca (Medicago Sativa L.) Kuru Otunun Ham Protein, Selüloz ve Bazı Mikrobiyolojik Özelliklerinin Belirlenmesi, Yüksek Lisans Tezi. NKÜ FBE, Tekirdağ, Türkiye, 2014.

[16] Alataş MS., Kara K., İnal F., Kahraman O., Özbilgin A., Coşkun B. Comparison of alfalfa (medicago sativa) energy values estimated by using the nrc-2001, hohenheim and uc davis equations. Kafkas Univ Vet Fak Derg 2016; 22 (5): 785-792.

[17] Engin B., Mut H. Farklı yonca çeşitlerinin ot verimi ve bazı kalite özelliklerinin belirlenmesi, YYÜ Tar. Bil. Derg 2017; 27 (2): 212-219.

[18] Abaş İ., Özpınar H., Kutay CH., Kahraman R., Eseceli H. Determination of the metabolizabl enerji (me) and net energy lactation (nel) contents of some feeds in the marmara region by in vitro gas tecnique, Türk J Vet Anim Sci 2005; 29, 751-757.

[19] Canbolat Ö., Karaman Ş. Bazı baklagil kaba yemlerinin in vitro gaz üretimi, organik madde sindirimi, nispi yem değeri ve metabolik enerji içeriklerinin karşılaştırılması, Tarım Bilimleri Dergisi 2009; 15(2): 188-195.
[20] Artan H., Polat T. Şanlıurfa sulu koşullarında bazı çok yıllık sıcak mevsim buğdaygil yem bitkisi türleriyle yoncanın saf ve karışık ekimlerinde yem kalite değerlerinin belirlenmesi, Harran Üniv Vet Fak Derg 2019; 8(1): 85-92.

[21] Karay1lanlı E., Ayhan V. Investigation of feed value of alfalfa (medicago sativa 1.) harvested at different maturity stages. Legume Research 2016; 39, 237-247.

[22] Kaya Ş. Kaba yemlerin değerlendirilmesinde göreceli yem değeri ve göreceli kaba yem kalite indeksi, Türk Bilimsel Derlemeler Dergisi 2008; 1(1): 59-64.

[23] Sheaffer CC., Peterson AA., Mccalin M., Volene JJ., Cherney JH., Johnson KD., Woodward WT., Viands DR. Acid detergent fiber, neutral detergent fiber concentration and relative feed value, North American Alfalfa Improvement Conference, 1995, Minneapolis.

[24] Başbağ M., Çaçan E., Sayar MS. Bazı buğdaygil bitki türlerinin yem kalite değerlerinin belirlenmesi ve biplot analiz yöntemi ile özellikler arası ilişkilerin değerlendirilmesi, Tarla Bitkileri Merkez Araştırma Enstitüsü Dergisi 2018; 27(2): 92101.

[25] Lacefield GD. Alfalfa hay quality makes the difference. University of Kentucky, Department of Agronomy AGR-137, 1988, Lexington, $\mathrm{KY}$.

[26] Linn JG., Martin NP. Forage quality tests and interpretations $1999 . \quad$ (Erişim: http://extension.umn.edu/distribution/livestoc ksystems/ID2637.html.)(Erişim Tarihi: $16 / 05 / 2019$ )

[27] Sayar MS., Kendal E. Tek y1llık baklagil yem bitkilerinin tahıllarla karışık ekimi, Mardin Gıda Tarım ve Hayvancılık Dergisi 2014; 4(11): 52-54.

[28] Schroeder JW. Interpreting forage analysis. Extension Dairy Specialist (NDSU), AS1080, 1994, North Dakota State University.

[29] Kutlu HR., Çelik L. Yemler Bilgisi ve Yem Teknolojisi. Ç.Ü.Z.F. Genel Yayın No:266. 
Ders Kitapları yayın No:A-86. 5. Baskı. 378 s. Ç.Ü.Z.F. Ofset Atölyesi, Adana, 2018.

[30] Kaya İ., Öncüer A., Yıldız S. Kars ili çayır kuru otu numunelerinin besin madde içerikleri ve rumende yıkımlanma özellikleri, Vet. Bil. Derg 2003; 19(1-2): 33-38.

[31] Kökten K., Kaplan M., Seydoşoğlu S., Özdemir S., Boydak E. Farklı yerfistığ (arachis hypogaea) çeşitlerinin kuru otlarına ait hayvan besleme değerlerinin belirlenmesi, Türk Tarım ve Doğa Bilimleri Dergisi 2014; 1(2): 156-160.

[32] Larbi A., Dung DD., Olorunju PE., Smith JW. Tanko RJ., Muhammad IR., Adekunle, IO. Groundnut (Arachis hypogaea) for food and fodder in crop-livestock systems: forage and seed yields, chemical composition and rumen degradation of leaf and stem fractions of 38 cultivars, Animal Feed Science and Technology 1999; 77, 33-47.

[33] Savadogo M., Zemmelink G., Nianogo AJ. Effect of selective consumption on voluntary intake and digestibility of sorghum (Sorghum bicolor L. Moench) stover, cowpea (Vigna unguiculata L. Walp.) and groundnut (Arachis hypogaea L.) haulms by sheep, Animal Feed Science and Technology 2000; 84, 265-277.

[34] Abdou N., Nsahlai IV., Chimonyo M. Effects of groundnut haulms supplementation on millet stover intake, digestibility and growth performance of lambs. Animal Feed Science and Technology 2011; 169, 176-184. 